\title{
The Progressive Dilemma and the social democratic perspective
}

\author{
Steven Fielding and Declan McHugh
}

The object of this chapter is to consider the notion of the 'progressive dilemma' as outlined by David Marquand in his collection of essays of the same name (Marquand 1999). Marquand sought to explain Labour's historically poor electoral performance by focusing on the party's inability to unite a sufficient number of working-class and middle-class voters in a sustained anti-Conservative coalition. As will be explained in more detail later, he believed Labour's attachment to the trade unions was too close and prevented the party making a strong appeal to those outside the labour movement.

Marquand was by no means the first academic to alight on this as possible cause of Labour's disappointing electoral performance (for example, see Stedman Jones 1983). However, the particular means by which he explained Labour's failure enjoyed a unique purchase among students of the Party, as well as those most responsible for the creation of 'New' Labour. Many of Tony Blair's early speeches delivered as leader owed more than a little to Marquand's perspective. One of the 'New' Labour leader's closest advisers, Phillip Gould, even used it to justify the policy and organisational changes fostered by Neil Kinnock and Blair since 1983 (Gould 1998: 1-17). Despite Marquand's own reservations about 'New' Labour, the perspective outlined in The Progressive Dilemma obviously resonated with those pursuing what Blair described during the 2001 election campaign as a 'radical, modern, social democratic' agenda. Indeed, as Marquand (1997: 78-9) conceded after Labour's 1997 landslide victory, 'modernisers' like Blair had gone some way to resolving his 'dilemma'.

The Progressive Dilemma is here taken as the exemplar of a wider 'social democratic' interpretation of the Labour Party. There are, in truth, few historical accounts that explicitly employ this form of analysis - but only because it is such an insidious a part of many leading authorities' 'common-sense' view of the party (see in particular, Crewe and King 1995: 3-26 and Williams 1979). Marquand's work is worthy of close attention, not the least because he is rare in foregrounding many of that tradition's most significant assumptions and he employs them in a particularly lucid manner. 
It should nonetheless be borne in mind that the social democratic view of the party, like all others, has not stood still. Thus, The Progressive Dilemma was the product of a particular moment - after the collapse of the Social Democratic Party (SDP) in the late 1980s but before Blair assumed the Labour leadership in $1994-$ in the history of British social democracy. Therefore, while Marquand aspired to present an interpretation of general historical relevance, it is a product of its time. Consequently, the chapter first historicises The Progressive Dilemma before scrutinising it as a piece of political analysis.

\section{Social democrats and Labour}

Before outlining the social democratic perspective, it is necessary to characterise the outlook of those described as social democrats; in accomplishing this task the work of Peter Clarke (1983) is particularly useful. Clarke was interested in those intellectuals-cum-politicians who wished to gain control of the State through democratic means so as to create a more equal society. This could be achieved, they believed, within a reformed capitalism, one in which most of the damaging consequences of a wholly free market had been curtailed by government action. While the chapter is also concerned with those who took a leading role in formulating this social democratic outlook, not all of its adherents, it should be stressed, were Oxbridge-educated, academically inclined, aspiring cabinet ministers. For, while Labour activists are regarded as drawn predominantly to radical socialism, a substantial minority taken from solidly proletarian backgrounds looked favourably on social democracy. Thus, in the early 1960s' fight against the Left's attempt to win Labour over to unilateral nuclear disarmament, the parliamentary leadership won the support of over half of conference delegates (Hindell and Williams 1962). During this period, social democrats attempted to give a lead to supporters in the country by creating the Campaign for Democratic Socialism (CDS). Despite some early success, however, they let the CDS fall into abeyance and thereby allowed the Labour Left freedom to extend its influence within constituency parties (Brivati 1996: 359-64, 380-403).

According to Clarke, social democratic intellectuals were committed to an ultimately untenable position. They saw the promotion of class conflict as an undesirable, indeed unnecessary, means of achieving their ends: as the future Labour Cabinet Minister Anthony Crosland stated in the 1950s, there was no irreconcilable conflict' between the classes. Social democrats looked on co-operation as the best, if not the only, way of advancing their cause. Instead of promoting the interests of a particular social group, they wished to mobilise a communal interest that transcended class. Despite this, for much of the twentieth century the majority of social democrats found themselves identifying with, belonging to and sometimes leading a Labour Party seen by many of its supporters in the trade unions as a 'class' party. Moreover, many such trade unionists expected it to advance their particular interests - at the expense of others', if necessary. 
Even so, not all social democrats worked within Labour's ranks. In particular when the New Liberals - Edwardian Liberal intellectuals who approved a significant degree of state intervention to promote a more equal society - considered leaving their disintegrating party and joining Labour after 1918, they had to ask themselves a difficult question. Could they accept the union influence within the party? Some answered this question in the negative: the economist John Maynard Keynes was one of those who remained in the Liberal Party (Desai 1994: 50-2). Indeed, whether such 'progressive' thinkers should join with Labour, for all its apparent shortcomings, or stand aloof and passively contribute to the continued success of the Conservatives, lies at the heart of Marquand's dilemma. Clarke claims that those social democrats working within the party resolved the contradiction between some of the implications of their outlook and Labour's apparent character by accepting the self-interested nature of the labour movement. Ingenuously, however, they persuaded themselves that the unions' claims for redress were consistent with their own aim of social justice. On the way to a more equal society, the demands of the unions would of necessity have to be met; as Clarke (1983: 15-16) puts it, the unions' self-interest was conceptualised as 'incipient altruism'.

\section{Living with the unions}

While Labour's 1918 constitution was not considered ideal, given the extent of the influence which it granted the unions, it still had its advantages. Writing in the early 1950s, the leading social democratic intellectual R. H. Tawney (1966: 177) believed the unions provided the party with 'broad popular foundations' that prevented Labour becoming dogmatic - unlike other continental left-wing parties which did not enjoy such close links with their indigenous labour movements. Moreover, the constitution enabled social democrats to lead the unions in directions they might not otherwise have taken. In 1955 Bill Rodgers, who would later help found the SDP, conceded that union dominance of the Labour Party Conference was sometimes 'undesirable'. 'The important thing', however, was 'to keep the trade unions in politics and on the side of Labour . . . [Trade union leaders] want to be liked: they even want to be guided' (Fielding 1997: 45-6). If this appeared arrogant, Rodgers's comments echoed those of Graham Wallas, made earlier in the century, that intellectuals like himself were charged with the 'duty of thinking on behalf of the working class' (quoted in Clarke 1978: 139). This sounded more like the assumption of an onerous responsibility and formed the basis for Hugh Gaitskell's opinion, that fellow-middle-class Labour MPs should observe a 'profound humility' towards the party's working-class supporters, as 'we've got to lead them because they can't do it without us, without our abilities' (quoted in Morgan 1981: 769-70). Marquand also bluntly suggested, though in more acrimonious times, that without social democratic intellectuals, Labour would have been 'all brawn and no brain': had the party achieved power without their guidance, it would not have had the remotest idea what to do with it' (1979: 9).

As Labour's social democrats are agreed to have attained their greatest influence within the party at mid-century, it is especially instructive to analyse what they 
thought of their political home at this point. Their outlook is best encapsulated in the 1960 CDS manifesto, which stated that social democrats viewed the party's 'central tradition' as 'a non-doctrinal, practical, humanitarian socialism - a creed of conscience and reform rather than of class hatred'. The labour movement, it went on, owed its inspiration to British radicals, trade unionists, co-operators, nonconformists and christian socialists, not to Marx or Lenin'. Moreover, the manifesto asserted, Labour 'should be a broadly-based national party of all the people ...A democratic socialist party must be based predominantly on working people. But a purely sectional, one-class party would . . be a betrayal of the ideal of a classless society.' Thus, the 'socialism' to which social democrats adhered was not 'an arid economic dogma' but one of 'freedom, equality, social justice and world cooperation' based on 'an idealistic appeal to remedy real evils by practical and radical reform' (quoted in Fielding 1997: 61-2).

Labour never fully adhered to the CDS vision, and as the 1960s gave way to the 1970s the party seemed to move ever-further away from its ideal. Under Gaitskell's leadership, social democrats had relied on the brute force of the union block vote to achieve their ends, viewing it as the lesser of two evils. Such a reliance on union power, however, brought fewer returns after 1966. Moreover, the identification of the unions as comprising a materially deprived working class became questionable: many trade unionists were by any measure fairly well off. By the late 1960s, a few social democrats came to view the unions as less like the universal-interest-inwaiting and more as a selfish, vested interest, just like any other. This minority began to consider that Labour's connection with the unions - indeed, with the working class as a whole - prevented the party achieving a socialism 'based on cooperation, neighbourliness and readiness to help other people. To such eyes, Labour's over-reliance on working-class voters also endangered social reform, as many workers virulently opposed black immigration, homosexuality, abortion, divorce and the abolition of capital punishment (Mayhew 1969: 94-5).

By the late 1970s, Rodgers's earlier confidence in the effect of his 'guidance' on the unions had disappeared. Writing of those years, he criticised Labour politicians for 'defer[ring] uncritically' to union demands; the unions, he stated, were locked into a time-warp, 'fighting a by now irrelevant "them" and "us" battle', despite the fact that social and economic change made class hostility irrelevant. Their influence, he asserted, undermined Labour's ability to 'have a mind' - presumably a social democratic mind - 'of its own' (Rodgers 1982: 167-70). By the start of the 1980s, a Labour Party that apparently allowed the unions such dominance appeared to some as an impediment to social democracy. The unions were certainly neither help nor hindrance in stopping the party's move leftwards. They were also at best uninterested in issues of importance to social democrats, such as individual freedom; opposed reforms thought necessary to revitalise the economy; were apparently unpopular with the electorate; and, finally, believed to not even represent their own members' views (Jenkins, Aaronovitch and Hall 1982: 16; Minkin 1991: 208-21). Even MPs who, like Denis Healey, were strongly influenced by revisionism but stayed within the Labour Party broadly agreed with much of this analysis (Healey 1990: 467-8). 


\section{David Marquand}

By the time David Marquand was helping to found the SDP he had been active in Labour politics for about 25 years. He entered the Commons in 1966 after a short career as a journalist. One of the second wave of Labour's post-war revisionists that included David Owen and Roy Hattersley, Marquand like them became part of Roy Jenkins's entourage. When Jenkins left the Cabinet in 1976 to become president of the European Economic Community, Marquand resigned as an MP and followed him to Brussells; when Jenkins returned to establish the SDP, Marquand assisted in the enterprise. Indeed, in 1979 he wrote - after voting Liberal in the general election of that year - what has been described as the SDP's 'founding text' in outlining why it had become impossible for those like him to remain loyal to Labour (Desai 1994: 178). In his essay 'Inquest on a movement: Labour's defeat and its consequences' (1979), Marquand argued that Labour had failed to develop into the organisation desired by social democrats. Instead, during the 1970s it had assumed the mien of an aggressive 'proletarianism'. This asserted that Labour should be 'not merely a predominantly but an exclusively working-class party; that the working class can be properly represented only by people of working-class origin who alone understand its aspirations and have its interest at heart'. The 'elaborate intellectual constructs' of middle-class progressives were consequently viewed as at best unnecessary, as 'the party can be guided much more satisfactorily by the gut reactions of its working-class members, and at worst positively dangerous, since they may lead the party away from its working-class roots'. The lesson drawn by the party from the industrial discontent of the 1970s was, Marquand believed, that people like him were now surplus to requirements (Marquand 1979: 14, 16).

Following more of an academic than a political career subsequently, Marquand became a Liberal Democrat when the SDP split between the Liberal-inclined Jenkinsites and the go-it-alone Owenites. Like a number of other social democratic émigrés he rejoined Labour after Blair became leader; in doing so, he announced that 'New' Labour was now an 'unequivocally social-democratic party' located in the 'mainstream of North European social democracy' (Marquand 1995: 18-19). In contrast to certain other ex-Labour MPs who joined the SDP, Marquand continued to advocate many of the policies associated with post-war Keynesian social democracy. It was not so much Labour's social democratic policies which had been at fault, he suggested: instead, the triumph of Thatcherism had derived more from the flawed political practices employed by successive Labour Governments to enact them. Like many of those who left Labour, Marquand became increasingly preoccupied with the forms in which politics was articulated. If he did not question the basic intellectual foundations of much of post-1945 social democracy, Marquand (1988) explored different constitutional means of ensuring its successful implantation in British society. Thus, on the basis of his desire for constitutional change but continued faith in some of the assumptions underlying Croslandite social democracy, Marquand became a keen critic of 'New' Labour. 


\section{The Progressive Dilemma}

Publication of The Progressive Dilemma occurred at a particularly pregnant moment in British political history. As Marquand characterises the period, the neo-liberalism of the 1980s was on the wane, Margaret Thatcher having been displaced as prime minister after the poll tax revolts. There was a 'new mood' stressing the drawbacks of the form of capitalism engendered by the Thatcher Governments' neo-liberal reforms. To address these problems, a 'new intellectual and political paradigm' had emerged which combined insights from 'traditional social liberalism' and 'traditional social democracy' (Marquand 1991: 227-30). At the same time, Kinnock's 'modernisation' of Labour's formal attitude to key areas of policy made some observers believe that he was moving the party from 'its distinctively British, labourist roots' and transforming it into a 'social-democratic party on the European model' (Mulgan 1989: 28-9). Such a body should have been the ideal agency for putting the rapprochement between liberalism and socialism into practice. Indeed, given the slump in the fortunes of the centre parties since the SDP-Liberal merger, Labour appeared to be the only practicable means of advance. Marquand, however, looked on that prospect with a sceptical eye. If yet hopeful that the divided anti-Conservative majority would unite, he believed Kinnock's Labour was still too much in awe of the unions to allow it to assume command (Marquand 1989:375-8). The Progressive Dilemma was Marquand's attempt to think these matters through.

The ostensible focus of Marquand's celebrated essay was Labour's inability to hold national office for much longer than a single term. The party, at the time Marquand wrote, had only twice won a working Commons' majority, but neither the 1945 nor the 1966 victory led to a sustained period in power. Marquand considered Labour's inability to make a strong appeal to those beyond the manual working class as the key reason for this failure. The party, he argued, was tied too closely to that group, to the industrial trade unions, in particular, to construct a long-term socially diverse anti-Conservative coalition. The basic reasons for Labour's poor record were its 'structure and beliefs', its very nature - at least as codified in the 1918 constitution. Had Labour's character been different - had the party assumed the one outlined by Marquand - its electoral record would have been more respectable.

According to Marquand, Labour should have emulated the model established by the Liberal-led Edwardian 'progressive alliance'. Indeed, he effectively argued that it would have been better all round had Labour not sought independence but remained within a coalition 'reconstituted' to take better account of the unions' interests (Marquand 1991: 18-20). He appeared to believe that, had it not been for the First World War, and had Labour been sufficiently patient, the Liberals would have accommodated the working class on more favourable terms than those on offer prior to 1914. Even so, the Liberals between 1906 and 1914 had tried to establish a 'middle way' between laissez-faire capitalism and the collectivist State. The New Liberals, most notably, hoped to chart a course between capital and labour with the aim of incorporating the labour movement within a suitably reformed 
capitalism. Marquand was not slow to suggest that such a programme anticipated those embraced by post-war European social democrats in general and Labour figures such as Gaitskell in particular.

The appropriate political context for the enactment of these policies was, he suggested, one where the unions formed part of a 'broad-based, cross-class coalition', and within which they could enjoy a 'crucial, but not dominating, part'. Marquand suggested that this arrangement - similar to the vision of the CDS - was more than feasible by pointing out that it had been achieved elsewhere. The Democrats in the USA and most other European social democratic parties had built similar multiclass coalitions. Britain was the exception, for here the labour interest dominated, and was indeed embodied in, the Labour Party. As he asserted, Labour 'deliberately' - and, on the basis of his analysis, perversely - chose to 'identify itself as the instrument of the labour interest rather than as the vehicle for any ideology'. Thus,

in a sense not true of its social democratic counterparts on the mainland of Europe, it has been a trade union party, created, financed and, in the last analysis, controlled by a highly decentralised trade union movement, which was already in existence before it came into being. Above all, its ethos - the symbols, rituals, shared memories and unwritten understandings, which have shaped the life of the party and given it its unmistakable identity - had been saturated with the ethos of trade unionism. (1991: 17)

As Labour was so tied to the unions, reflecting their defensive 'us-and-them' labourist outlook to the exclusion of all others, the party enjoyed solid support in its proletarian fortresses but could evoke little enthusiasm beyond them. Agreeing that parties enjoy the ability to 'shape' voters' attitudes and transform their appreciation of their own interests, Marquand stressed how Labour's internal character prevented it from addressing those outside its union-dominated redoubts in language that may have evoked a more positive response. The party's essential reliance on a 'class' appeal meant that it was incapable of making the intellectual leap necessary to draw in those for whom class meant little - or something different from what it meant to those in the heartlands. The confining 'structure and mentality' of the unions meant, therefore, that Labour lacked the necessary political imagination to sustain itself in office. Here the progressive alliance's very heterogeneity was seen as giving it a further advantage over its 'labourist' successor. As Marquand wrote elsewhere, for much of the post-war period, Labour had sought to use the State merely to protect workers in declining industries against the consequences of economic change. As Labour had based its electoral appeal on its ability to provide material improvement, it possessed no moral language that might have appealed to those less dependent on that kind of protection (Marquand 1988: 19-20, 141-3, and 1989: 375-8). It would have been so much better had Labour approached the electorate in a different manner: it did not - could not - do so because of the kind of organisation it was.

Marquand's essay contains many subtle points that do not bear compression, yet it proceeds, in effect, from the following five assumptions.

- The Liberals were not a spent force and could have fully integrated the labour interest within a progressive alliance had it not been for the First World War. 
- Labour's own nature, confirmed in the 1918 constitution, prevented it from 'shaping' non-working-class voters' preferences.

- Had Labour assumed a different character - akin to the New Liberals' - it would have enjoyed a happier electoral history.

- Within continental social democracy, Labour was the exception rather than the rule: the experience of other countries confirmed the feasibility of Marquand's model.

- Social democracy's failure was due less to programmatic weakness and more to the flawed means by which it was articulated.

Marquand's view of Labour was influenced by considerations which feature in accounts that could in no way be described as social democratic: hence the belief in British exceptionalism in general and of Labour in particular,and the related assumption that it embodied a 'labourism' directly traceable to the outlook of manual trade unions. If Marquand and other social democrats saw this 'labourism' as blocking the development of social democracy, then socialists such as Ralph Miliband and John Saville saw it in similar terms with regard to their own political ambitions (Fielding 2000). Closer to home, the account was influenced also by a keenly contested historiographical debate about the electoral viability of the Liberals after 1914. In particular, Marquand was impressed by Clarke's optimistic account of Edwardian Liberalism's engagement with class politics. Indeed, belief in the viability of the Liberal Party is probably one of the two hallmarks of many late twentieth-century social democrats. The other is that Labour was too closely tied to the trade unions to have been a successful vehicle for social democracy. It is now time to scrutinise those two assumptions in the light of some of the available historical evidence.

\section{The progressive alliance}

To test Marquand's key historical suppositions, it is useful to concentrate on the first quarter of the twentieth century and make particular reference to the situation in Manchester. Historians generally regard Manchester as one of the most clear-cut examples of harmonious Liberal-Labour relations prior to 1914 and in that partnership the Liberals are thought to have held the whip hand (Clarke 1971; Tanner 1990: 157). It might be thought that if the progressive alliance was on the verge of collapse in Edwardian Manchester then important questions should be asked of its future in less favoured locations across the country.

In his study of politics in industrial Lancashire, the product of a $\mathrm{PhD}$ supervised by Henry Pelling, Clarke claimed that although social class was an increasingly important factor in determining political affiliations prior to 1914, it did not guarantee Labour's rise. Rather, he argued that the Liberal Party, by adopting policies such as old-age pensions and national insurance, and by virtue of its electoral pact with Labour, was set for a bright future as the senior partner in a progressive alliance. As evidence of the successful operation of this coalition, he referred to the situation in Manchester, where Lib-Lab cooperation had transformed a Tory 
citadel into a progressive heartland. Ostensibly, the Lib-Lab understanding offered considerable advantages to both sides, and, according to Clarke and others, was growing stronger on the eve of 1914 (Adams 2000: 29; Tanner 1990:157). Closer inspection suggests this to be a rather sanguine view. By looking at relations between the parties more closely, it is clear that even in Manchester tensions were becoming unmanageable and were boiling over well before the outbreak of the First World War (McHugh 2002).

As early as 1907, municipal elections had become the occasion for LiberalLabour conflict in Manchester. While most local Liberal Associations fought shy of standing against Labour candidates, some supported Conservatives in the hope of defeating their putative partner. In 1908 Liberals and Conservatives went so far as to run joint-Independent candidates in two Labour wards (Manchester Guardian, 3 November 1908; see Nuttall 1908). The Liberal Party was, then, not exactly united in its adherence to progressivism: a significant number of its members were very close to the Conservatives. Indeed, in the years immediately after 1918, when their organisation had fallen into disarray, a substantial minority of Liberal councillors sat on the Conservative benches in Manchester's municipal chamber (Manchester Guardian, 5 and 12 October 1920).

Many Labour activists were also unhappy about cooperating with the Liberals. Prior to the 1910 municipal elections those wishing to make the break to independence formed a Socialist Representation Committee (SRC) in the city. The SRC aimed to 'promote Socialist Representation on public bodies, and to form a National Socialist Party, uniting all militant socialists' (Clarion, 21 July 1911). Within a year, the Manchester SRC had joined with others to form the British Socialist Party (BSP), which held its foundation conference in neighbouring Salford, attracting numerous ex-Labour supporters into its ranks. It was to halt the flow of defections to this new body that the Manchester and Salford Labour Representation Committee (MSLRC) took steps to emphasise its autonomy by aiming to contest Liberal seats in what would have been the 1915 general election (MSLRC 1912). This belligerence provoked a greater determination on the part of certain Liberals to call for an end to their party's alliance with Labour (Hertz 1912: 93; Manchester Liberal Federation 1913).

Most Liberals hoped to avoid conflict by supporting electoral reform, principally some type of proportional system. This would allow both parties, advocates believed, to compete in the same seats without splitting the anti-Conservative vote. This suggests that specific ideological inconsistencies were not the main bone of contention for most Liberals. Rather, the unwillingness of many members to concede their own position to Labour owed much to the socially constructed 'tribalism' that underpinned organised politics. More than differences in political outlook, however, the division between Liberals and Labour rested on the contrasting class composition of the two parties. It had, after all, been the refusal of the Manchester Liberal Union (MLU) to run working men candidates before 1900 that had given impetus to the creation of the MSLRC in the first place. Dominated by a wealthy elite, the MLU was happy to represent workers, even tailoring some of the party's policies to suit their needs, but members did not want to be represented 
by proletarians. As a result, the Independent Labour Party converted the Manchester and Salford Trades Council, which acted for skilled trade unionists historically close to the Liberals, to independent labour representation. Subsequently, the Trades Council played a key role in the formation of the MSLRC, a development that effectively ended the possibility of organised labour ever being subsumed within local Liberalism (Hill 1981: 192-7).

Thus, social differences, as much as political disagreements imperilled the longterm survival of the 'progressive alliance' in Manchester. Indeed, it is arguable that it would have survived the General Election due to be held in 1915. Despite good intentions at the national level, differences among local activists were profound and set to end the possibility of cooperation. In this process, Manchester was typical of other towns and cities across Britain where the progressive alliance showed signs of weakness even before 1914 and afterwards quickly unravelled (Belchem 1996; Berger 1993).

\section{The 1918 constitution}

If the continuation of the Lib-Lab coalition was in doubt even prior to the intervention of the First World War, the repercussions of the European conflict made its demise certain. The split in the Liberals and the proposal to extend the franchise to all men and most women presented Labour with a chance to become the main anti-Conservative alternative. Recognising this opening, the party's leadership devised a plan for Labour's reorganisation, which they hoped would transform it from a trade-union pressure group into a national independent body capable of winning majority support. Thus, Labour's membership had to be broadened, its machinery made sound and the party equipped with a comprehensive programme serving an ultimate aim (Fabian News, 29 (1918): 6; Henderson 1918).

According to Marquand, the choices made at this juncture would prove fatal. Instead of creating a pluralistic party and furnishing Labour with a programme that meshed 'labourism' with Liberalism, the leadership re-established Labour, as Gould put it, as 'a socialist party immutably linked to trade unionism. Clause 4 , in particular, committed Labour to pursuing public ownership as its ultimate goal, while concessions to the unions confirmed their dominance over the annual conference and the National Executive Committee. As a result, 'discipline was gained, but flexibility and the influence of ordinary members was weakened'. The capacity to 'modernise and adapt was to be the ultimate casualty', while other 'possible options, which were still open at the start of the century, were closed down' (Gould 1998: 26-7).

There is some truth in this argument. Powers granted to the unions proved crucial in shaping Labour's future path. At critical moments in the party's history notably Gaitskell's thwarted attempt to revise Clause 4 and Harold Wilson's efforts to reform industrial relations in 1969 - the unions vetoed moves that would have significantly altered the course of both party and national history. Moreover, the unions' influence could be felt throughout the organisation: because they offered Labour unrivalled access to money, personnel and facilities the unions often dominated branches in industrial areas. 
It is doubtful that there could have been any other outcome in 1918. Those most responsible for change nonetheless strove to transform Labour from a union pressure group to a party open to all classes. As Arthur Henderson, then party chair, explained (1918: 124), the new constitution sought to make Labour 'the party of the producers - of the workers, in the widest sense of that noble word: of all the people, without distinction of class or sex, who labour to enrich the community'. The adoption of Clause 4, with its references to 'workers by hand or brain', was meant to further that process and was not designed to cast Labour in a classconscious socialist mould. Indeed, the ideological aspect of the constitution was largely ignored at the time - although it came to attract substantially greater interest in later years.

Far more important to contemporaries were the structural changes instituted by the new constitution, and here the unions largely enjoyed their own way, if only on a quid pro quo basis. Nevertheless, the agreement to construct a national network of local parties, populated for the first time by individual members, was a significant step. Indeed, some hoped that these new branches would drain power away from the unions. Herbert Drinkwater, one of Labour's senior organisers, claimed (1923: 15) that 'individual membership had in it the genesis of a revolutionary transference of weight and power within the party'. For him, 1918 was 'nowhere a final and last word regarding [Labour's] structure . . . it will adapt itself to circumstances as it grows' (Drinkwater 1921: 7).

If the unions remained the formally dominant force in Labour's organisation, this was not necessarily meant to be a permanent state of affairs. Eventually, it was hoped, power would be devolved to the members, a development seen to be crucial if Labour was to become a truly national body. For, according to Sidney Webb (1917: 152), it was through the provision of individual membership that 'those younger men who have enjoyed the advantages of a wider education than the workman can secure, and of a training other than that of life at the forge, [will] come into the Labour Party'. Many of these, it was anticipated, would be former Liberals who were thought to be 'looking longingly' at Labour from their slowly sinking ship (Wilson Harris 1917).

In essence, Labour's leadership strove to achieve precisely the results that Marquand has accused them of neglecting. Indeed, in some respects, the changes implemented in 1918 represent the original 'New' Labour project - an attempt to broaden Labour's political and electoral scope by loosening the grip of the unions. While not exactly a great success, these reforms were by no means a complete failure. After all, several commentators - in particular Lewis Minkin - believe that the powers enjoyed in theory by the unions often amounted in practice to less. This was, they consider, largely due to the fact that most unions did not want to dictate to the party leadership, fearing the wider electoral consequences should they do so. The formula defining how relations between MPs and the unions-dominated conference was in fact agreed as early at 1907. This stipulated that parliamentarians enjoyed the final power to determine the 'time and method of giving effect' to conference decisions - a discretion they went on to exploit with some gusto (Minkin 1978: 5-6 and 1990). 
Even in the immediate wake of 1918, Ramsay MacDonald showed little concern for union sensitivities, and during the 1920s he represented his party as a body that sought to transcend notions of class through a commitment to create 'community'. In 1929 Labour achieved a level of electoral strength that suggested it was developing support both within and without its working-class bastions. Had the second Labour Government of 1929-31 operated in more benign economic circumstances, MacDonald may have eventually resolved Marquand's 'dilemma'. The onset of a world depression and the difficult choices that followed drew the curtain down on that possibility. It also shifted power back to the unions - but only because the PLP had been smashed at the 1931 general election and was bereft of effective leadership after MacDonald defected to form a National Government (Riddell 1999).

For much of the post-war period, Labour leaders enjoyed a near-autonomous position within the party, one deriving from the largely unconditional support of the largest unions. This gave Hugh Gaistkell and Harold Wilson, in particular, the freedom to pursue electoral strategies designed to appeal to moderate 'floating' voters outside of the labour movement. When this autonomy came to an end, in the 1970s and 1980s, it was due largely to the demands of the party's radicalised active members, rather than the unions. Ironically, given Marquand's complaints about the party's 'proletarianism' at that time, Labour's activists were increasingly middleclass in origin. Moreover, those working to end their leaders' freedom of action and supporting policies meant to serve working-class interests over all others were led by the former hereditary peer Tony Benn (Whiteley 1983: 53-80).

\section{No alternative?}

On the whole, the 1918 constitution failed to create a greater distance between Labour and the unions and thus, it could be argued, handicapped the party's development. Against that view, some final comments should be made.

First, if the 1918 constitution did not develop in the ways intended, that was not necessarily due to the actions of Labour's leadership. At least in part, the failing was down to 'the people', who simply could not be induced to join and become active in the party. Although it might be argued that it was because they were alienated by the image and operation of the party machine that people did not commit to Labour, the reasons for popular political inactivity were more deep-rooted (McHugh 2001: 147-74).

Second, even accepting that the changes instituted in 1918 were defective, it is doubtful that another, more attractive, course was open. While some may lament Labour's trade union origins, those origins remain a fact, and one that restricted the leadership's room for manoeuvre. Indeed, before he temporarily gave up on Labour as a vehicle for progressive change, even Marquand accepted this. In his biography of MacDonald (1977: 229), he conceded that in the circumstances of 1918, Henderson's constitution was probably the best obtainable'. The unions were being asked to pay higher affiliation fees - essential if Labour was to compete in an enlarged electorate - and 'they were hardly likely to do so without a quid pro quo'. 
Consequently, in the context of the time, the party that emerged, although by no means an ideal body for the promotion of social democracy, was the best on offer. As Henderson asked Labour's 1918 Conference delegates, while they considered his proposed new constitution:

\begin{abstract}
Should they have no longer a Federation and begin to build up from a new foundation a political organisation depending only upon individual membership? Speaking as an old electioneer he did not mind saying that if he had to begin afresh that would be the goal at which he would aim ... But apart from the nearness of a general election it would be practically impossible to attempt such a course. Imagine the Executive saying to the Trade Unions upon whom the party had depended that they had no formal use for them. He thought the Conference would give short shrift to such a proposition. (Labour Party 1918: 99)
\end{abstract}

It is this point that is often lost on some, at least, of Labour's social democratic critics. Eager to argue that things should have been much different, they can go too far in asserting that things could have been much different. At least one reading of Labour's history, however, suggests that party leaders in 1918 had few options open to them. The party had been established with the crucial help of the unions and without their continued support its future was uncertain: the alternative of a truly membership-based party appeared too much of a risk. With the unions Labour may have been a flawed vehicle for progressive politics; but without them, as Robert Taylor (2000: 43) has firmly put it, it would have been 'nothing'. The history of the SDP indicates the wisdom of the 1918 settlement. Unlike Marquand and colleagues in the 1980s, Henderson and Webb appreciated the electoral, financial and organisational strengths offered by the unions, and realised that at least for the time being it was impossible to proceed without them.

\title{
The progressive dilemma resolved?
}

By now it should be clear that the social democratic interpretation of the Labour Party, as exemplified by The Progressive Dilemma, should be viewed with some caution. Its central proposition, regarding the role of the unions, was the product of a particular political tradition with its own peculiar trajectory. In this generic sense, the social democratic perspective is just like any other: self-interested, partial and subject to variation over time. It should not be assumed, however, that by criticising the social democrats in such terms, we adhere to some alternative analytical 'golden mean', for none presently exists. It might, indeed, be ventured that if the social democratic interpretation was flawed, it possessed fewer faults than those propounded by Labour's many socialist critics.

To question the social democratic perspective, two of Marquand's central contentions have been scrutinised in the light of the evidence that presently exists. That exercise has revealed the extent to which this viewpoint was informed as much by hopeful speculation about how the past should have been as it was by sober analysis of real historical possibilities. Again, it would be wrong to condemn 
social democrats as uniquely unsound in this respect: many historians travel backwards determined to discover what they have already decided to find.

In conclusion, there is a final thought that further undermines the utility of the social democratic approach. One of Marquand's key propositions was that, had Labour been able to alter its character in such a way as to make a sustained appeal to those beyond the 'traditional' working class, it would have enjoyed a rosier electoral history. This presumed that Labour's gains within the middle class would not have been offset by losses in the working class, a view sharply contradicted by Adam Przeworski's analysis of the electoral history of European Social Democracy. For he discerned that as soon as Centre-Left parties reduced the salience of class in their electoral strategies, so as to appeal to middle-class voters, they found it all the harder to mobilise workers' support (see Przeworski and Sprague 1986: 57-79).

Table 9.1 The Labour vote, 1964-70

\begin{tabular}{lcccc}
\hline & 1964 & 1966 & 1970 & Difference 1964-70 \\
\hline Higher service & 18 & 19 & 22 & +4 \\
Lower service & 20 & 29 & 32 & +12 \\
Routine non-manual & 26 & 41 & 40 & +14 \\
Petty bourgeoisie & 15 & 20 & 20 & +5 \\
Foremen/technicians & 48 & 61 & 56 & +8 \\
Skilled working class & 70 & 73 & 63 & -7 \\
Unskilled working class & 66 & 70 & 61 & -5 \\
\hline
\end{tabular}

Source: Evans, Heath and Payne (1999: 90).

British election survey data generated during the 1960s endorses Przeworski's pessimism over Marquand's optimism. In the general election of 1966 Wilson increased his party's appeal to voters in all social classes compared to 1964 (see Table 9.1). The result was a Labour majority in the Commons of some ninetyseven seats, which included the newly elected MP David Marquand. In office, Wilson's ministers believed they would best maintain that majority by continuing to do what they had done for some years: pitch their policies most directly at fickle suburban voters with no attachment to the labour movement. They imagined that the manual working class would remain that which they had always been: loyal Labour voters (Fielding 2004: chapter 2). The result of the 1970 general election showed the disadvantages of this eminently social democratic strategy: while Labour held on to or even increased non-manual support won during the 1964-66 period it lost support in the working class and found itself once more in opposition (Butler and Pinto-Duschinsky 1971).

As 'New' Labour approached re-election in 2001, many feared the party would suffer a similar fate. They believed Blair's focus on the concerns of 'middle England', which had helped him capture power in 1997, had to a dangerous degree alienated the party's working-class supporters (Fielding 2003: 85-115). In the end, the party held on to most, not all, of its non-manual voters but lost support within 
its working-class heartlands, although perhaps not to the extent that some Jeremiahs had forecast (Denver 2002). Unlike in 1970, however, Labour retained its majority. Given the expansion of non-manual and lightly unionised occupations, and given also the decline of the 'traditional' working class since the 1950s, this trade-off in votes was evidently acceptable to certain party strategists at the start of the new millennium. Time will tell how far this is a wise course to follow for the rest of the twenty-first century. It is, however, unlikely - despite Marquand's valiant attempt to convince us otherwise - that it would have been the electoral basis for a 'progressive' twentieth century.

\section{References}

Unless indicated, the place of publication is London.

Adams, T. (2000) 'Labour vanguard, Tory bastion or the triumph of New Liberalism? Manchester politics 1900 to 1914 in comparative perspective', Manchester Region History Review, 14

Belchem, J. (1996) Popular Radicalism in Nineteenth Century Britain

Berger, S. (1993) 'The decline of Liberalism and the rise of Labour - the regional approach', Parliamentary History, 22:1

Brivati, B. (1996) Hugh Gaitskell

Butler, D. and Pinto-Duschinsky, M. (1971) The British General Election of 1970

Clarke, P. (1971) Lancashire and the New Liberalism, Cambridge

Clarke, P. (1978) Liberals and Social Democrats, Cambridge

Clarke, P. (1983) 'The social democratic theory of the class struggle', in Winter, J. (ed.) The Working Class in Modern British History, Cambridge

Crewe, I. and King, A. (1995) SDP. The Birth, Life and Death of the Social Democratic Party, Oxford

Denver. D. (2002) 'The results: how Britain voted (or didn't)', in Geddes, A. and Tonge, J. (eds) Labour's Second Landslide, Manchester

Desai, R. (1994) Intellectuals and Socialism

Drinkwater, H. (1921) 'The constitution of the Labour Party', Labour Organiser, 6

Drinkwater, H. (1923) 'The outlook: from an organiser's standpoint', Labour Organiser, 35

Evans, G., Heath, A. and Payne, C. (1999) 'Class: Labour as a catch-all party?', in Evans, G. and Norris, P. (eds) Critical Elections

Fielding, S. (1997) The Labour Party. 'Socialism' and Society Since 1951, Manchester

Fielding, S. (2000) '“Labourism” and the British Labour Party', in the Collection de l'ecole francaise de rome - 267, Les Familles politiques en europe occidentale au XXe siécle, Rome Fielding, S. (2003) The Labour Party. Continuity and Change in the Making of 'New' Labour

Fielding, S. (2004) The Labour Governments, 1964-70, vol. 1: Labour and Cultural Change, Manchester

Gould, P. (1998) The Unfinished Revolution

Healey, D. (1990) Time of My Life, Harmondsworth

Henderson, A. (1918) 'The outlook for Labour', Contemporary Review, 113

Hertz, G. B. (1912) The Manchester Politician, 1750-1912

Hill, J. (1981) 'Manchester and Salford politics and the early development of the Independent Labour Party', International Review of Social History, 26

Hindell, K. and Williams, P. (1962) 'Scarborough and Blackpool: an analysis of some votes at the Labour Party Conferences of 1960 and 1961', Political Quarterly, 3:3 
Jenkins, P., Aaronovitch, S. and Hall, S. (1982) 'Redrawing the political map', Marxism Today, December

Labour Party (1918) Labour Party Annual Conference Report

McHugh, D. (2001) 'A mass party frustrated? The development of the Labour Party in Manchester, 1918-31', unpublished $\mathrm{PhD}$ thesis, University of Salford

McHugh, D. (2002) 'Labour, the Liberals and the progressive alliance in Manchester, 1900-14', Northern History, 39:1

Manchester Liberal Federation (1912) Executive Committee Minutes, 6 and 22 June, Manchester Reference Library Archive

Manchester Liberal Federation (1913) Executive Committee Minutes, 9 July, Manchester Reference Library Archive

Manchester and Salford Labour Representation Committee (1912) Letter to the National Executive Committee Elections Sub-Committee, NEC Minutes, 10 October, National Museum of Labour History.

Marquand, D. (1977) Ramsay MacDonald

Marquand, D. (1979) 'Inquest on a movement: Labour's defeat and its consequences', Encounter, July

Marquand, D. (1988) The Unprincipled Society

Marquand, D. (1989) 'Beyond Left and Right: the need for a new politics', in Hall, S. and Jacques, M. (eds) New Times

Marquand, D. (1995) 'Joining the "new” ship', New Statesman and Society, 6 October

Marquand, D. (1997) The New Reckoning, Cambridge

Marquand, D. (1999 [1991]) The Progressive Dilemma, 2nd edition

Mayhew, D. (1969) Party Games

Minkin, L. (1978) The Labour Party Conference

Minkin, L. (1991) The Contentious Alliance, Edinburgh

Morgan, J. (ed) (1981) The Backbench Diaries of R. H. S. Crossman

Mulgan, G. (1989) 'The vision thing', Marxism Today, August

Nuttall, J. (1908) Letter to Labour's national organiser, 5 November, LP/EP/08/1/113, National Museum of Labour History

Przeworski, A. and Sprague, J. (1986) Paper Stones. A History of Electoral Socialism, Chicago, IL

Riddell, N. (1999) Labour in Crisis. The Second Labour Government, 1929-31, Manchester

Rodgers, W. (1982) The Politics of Change

Stedman Jones, G. (1983) 'Why is the Labour Party in a mess?', in Stedman Jones, G., Languages of Class, Cambridge

Tanner, D. (1990) Political Change and the Labour Party, 1900-18, Cambridge

Taylor, R. (2000) 'Out of the bowels of the movement: the trade unions and the origins of the Labour Party, 1900-1918', in Brivati, B. and Heffernan, R. (eds) The Labour Party. A Centenary History

Tawney, R. H. (1966) 'British socialism today', in Tawney, R. H., The Radical Tradition, Harmondsworth

Webb, S. (1917) 'The reorganisation of the British Labor Party', New Republic, 8 December

Whiteley, P. (1983) The Labour Party in Crisis

Williams, P. M. (1979) Hugh Gaitskell

Wilson Harris, H. (1917) 'British Labor in the ascendant', New Republic, 1 December 